\title{
Influence of Critical and Economic Motivations on the Intention to Buy Second Hand Clothes of Vietnamese Consumers
}

\author{
Bui Thi Phuong Hoa \\ Faculty of Business Management \\ Hanoi University of Industry \\ Bac Tu Liem, Hanoi, Vietnam \\ hoabtp@haui.edu.vn
}

\author{
Quang Van Ngo \\ Faculty of Business Management \\ Hanoi University of Industry \\ Bac Tu Liem, Hanoi, Vietnam \\ quangnv@haui.edu.vn
}

\begin{abstract}
This study focuses on the impact of critical and economic motivations on the intention to buy second hand clothes (SHC) of Vietnamese consumers. Using quantitative research methods to conduct research. Survey sample of 823 consumers aged 18-41 years living in Vietnam. The data was analyzed and processed by SPSS 23 and Amos 23 software. The research results have shown that the critical and economic motivations have impacts on the attitude, which in turn influence the purchase intention of consumers. Besides, the low-price motive, which was mentioned as the main reason why consumers buy SHC, now only indirectly affects the intention to buy through the mediating variable. Especially for Vietnamese consumers, the critical motivation includes both the perception of sustainability and the anti-ostentation dimension.

Index Terms - second hand clothes, critical motivation, economic, motivation, attitude, intention.
\end{abstract}

\section{INTRODUCTION}

$\mathrm{A}$ CHIEVING environmental sustainability is an important issue for companies, even more so in some industries of development. Globally, the fashion industry is one of the industries with the most negative impact on the environment [26]. The explosive growth of fast fashion has made new styles quickly replaced and addition to low prices and the incentive for consumers to buy new clothes regularly [19]. A large amount of fashion products are not reused or recycled, but end up as waste in landfills or incinerated [26].

How to reduce the amount of fashion waste into the environment towards sustainable production and consumption is one of the issues that many countries, scientists, businessman and consumers are interested in. Buying SHC instead of buying new clothes is one of the solutions mentioned. Even shopping for SHC is said to be one of the most environmentally sustainable clothing choices[9]. Because, reusing clothes helps to extend the life of the clothes, reduce the amount of clothing thrown away, thereby reducing environmental pollution and waste of resources [12]. In addition, shopping for SHC is also said to be a measure to carry out a revolt against the fashion waste disposal phenomenon stemming from fast fashion consumption and usage trends $[6,30,35]$ as well as demonstrating resistance to the development of modern channels and avoiding large corporate chains [5]. Instead of buying clothes at the manufacturer's official sales channels such as retail stores, mail order / Internet, consumers buy SHC from informal channels such as buying from charity shops, stores and stalls selling SHC $[5,38]$. Several international reports actually predict that the second-hand clothing market can grow rapidly in fashion in the next 10 years [24].

Academic research on SHC consumption has received a lot of attention since the 2000s. Especially, when the consumption motivations or reasons to buy SHC are still not understood[3]. In addition, research directions that suggest critical motives as an official motive for the behavior of consuming SHC have been called for [4]. However, there are still many controversies surrounding the influence of this motive on consumers' intention to buy SHC. Therefore, this article is designed to understand the impact of economic motivations and critical on the attitude and intention to buy SHC of consumers in Vietnam.

\section{THEORETICAL BACKGROUND AND HYPOTHESES}

\section{A. Buy Second hand clothes}

Although historical evidence for secondhand traditions is well established (Hansen, 2000), marketing research on secondhand purchases is still scarce $[7,10,13,14,29,34]$. SHC is that has been used before and returned to the next consumption cycle. Therefore, previous studies have shown that one of the driving forces behind buying this product is the low price [6]. Other views of SHC have also been formed as unique products, in a fashion style that loves nostalgia or as ethical products whose consumption behavior is contributed to reducing the impact of environmental pollution on human life, as well as the waste of resources[12]. Therefore, consumers' buying behavior of SHC is changing and becoming more complex than before, requiring scholars and administrators to have deeper research to have appropriate solutions [14].

Previous studies identified different types of motivations for consumers to engage in second-hand shopping defined as psychological and physical motivations that drive consumers to second-hand products and/or channels [13]. This study focuses on economic and environmental reasons as these factors are likely to influence consumers' attitudes and intentions to buy second-hand clothing. Therefore, this study did not take into account constructs related to emotions and self.

\section{B. Critical motivations}

Many studies have shown that in modern society, the buying behavior of SHC is also influenced by critical motivations, which mainly come from two groups, the ethical and ecological dimension and the anti-ostentation[13]. 


\section{1) Ethical and ecological dimension}

Environmental and ecological issues have been addressed in the social fields [36], marketing [8, 25, 33], psychology [11], consumer behavior [14, 22, 28, 32]. Empirical evidence from these studies suggests that among the factors influencing consumer purchase of second hand, there may be reasons related to environmental sensitivities, such as trust or attitudes towards sustainability issues.

[8] found that the natural orientation, ecological influence and ecological knowledge of Chinese consumers, in addition to the collective level, also influence their attitudes towards green purchases. Based on a case study of Danish dairy consumers at two different points of sale, [33] found that people who buy organic milk display different selection methods compared to those who buy conventional milk. More specifically, an attribute of green consumption appears to enhance consumer participation in decision-making and signal greater consideration in their decision-making process. These results seem to be consistent with the literature on green purchasing behavior [32]. A more recent study of Indian consumers found that environmental concerns were associated with more positive attitudes towards purchasing green products[27]. Environmental reasons also emerged as the third appropriate motivation to buy second-hand products in a study focusing on IKEA consumers in Sweden [14].

Attitude towards performing a behavior refers to the degree to which a person has favorable or unfavorable judgment or evaluation towards that behavior in question [1]. It can therefore be argued that this would also apply to environments that may be dominated by environmental sustainability concerns, which could be reflected in a more positive view of purchasing SHC. So, it is suggested that:

H1a: Ethical and ecological dimension sustainability has a positive influence on attitudes towards buying SHC.

$\mathrm{H} 1 \mathrm{~b}$ : Perceived ethical and ecological dimension durability has a positive influence on the intention to buy SHC.

2) Anti-ostentation motivations

The literature reviewed $[10,13,29]$ shows that key drivers play a paramount role in triggering second-hand purchases. [13] identify an important feature of relationships related to how second-hand shoppers seriously participate in the broader market system, issues of consumerism, society consumption and consumption, and features and offers traditional channels.

Buying or consuming new goods is considered a typical waste of resources in a consumer society, while buying second-hand goods is tantamount to escaping the classical consumer market system, deliberately rejecting mass consumption and re-establishing consumers' sense of sovereignty, as well as adopting alternative channels to avoid conventional market channels [23]. Therefore:

H2a: Anti-ostentation motivations has a positive effect on the attitude to buy SHC.

$\mathrm{H} 2 \mathrm{~b}$ : Anti-ostentation motivations as a motivation to buy SHC positively affects attitude towards SHC purchase.

\section{Economic motivations}

The peer-reviewed literature on second-hand consumption suggests that economic drivers play an important role in influencing attitudes toward second-hand purchases [38]. [13] found that economic incentives are potentially relevant antecedents of second-hand purchase, whereas, [7] found that secondhand fashion purchases are positively influenced by thrift and bargain hunting. [34] revealed that the attractiveness of the price, specifically the lower price, positively affects the luxury purchase attitude of the former. Similarly, in a sample of university students, [39] show that price sensitivity or fair price is positively related to the frequency of purchases in second-hand clothing stores. [14] indicate that the main motivations for buying second hand products for IKEA customers are economic in nature. Therefore:

H3a: Low price motive to buy second hand positively affects buying attitude of SHC.

H3b: Low price motive has a positive effect on intention to buy SHC.

H4a: Fair price motive has a positive influence on buying attitude of SHC.

$\mathrm{H} 4 \mathrm{~b}$ : Fair price motive has a positive influence on the intention to buy SHC.

D. Attitude and intention to buy second hand clothes

Attitudes and purchase intentions have been examined by applying a number of models and frameworks rooted in psychology. Among these theoretical frameworks, the theory of reasoned action (TRA)[2] and the theory of planned behavior (TPB)[1] have gained considerable scientific recognition. Both of these theories postulate that a positive attitude towards performing a certain behavior precedes the actual intention to perform that behavior. For example, in the context of green product consumption, [27] shows that a positive attitude towards buying green products leads to a stronger purchase intention.

As such, consistent with TRA and TPB, this study hypothesizes that the drivers and perceptions identified in the previous subsections (perceptions of sustainability, distance from the consumption system, and economic force) positively affects second-hand purchases, which in turn positively affects behavioral intentions towards second-hand purchases. Thus, attitudes work as mediators between antecedents and intentions. Therefore, this research hypothesis that:

H5: Attitude towards buying second hand has a positive influence on behavioral intention to buy SHC

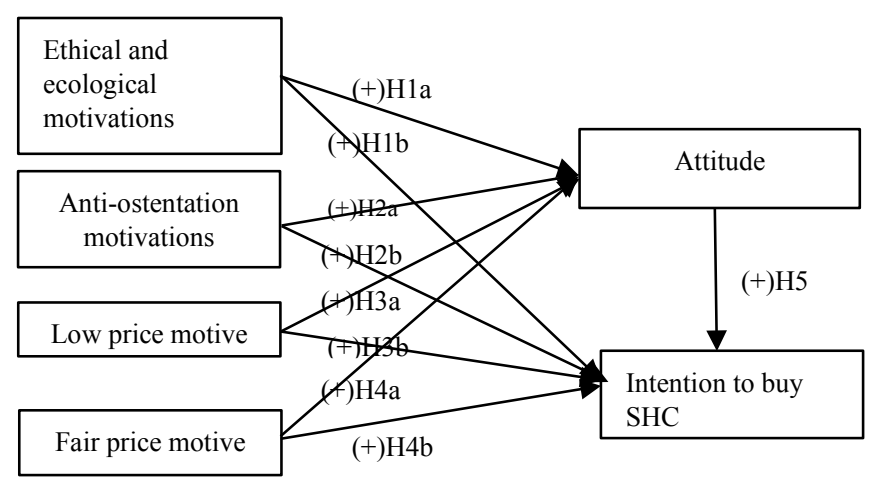

Figure 1. Proposed research model 


\section{Research Methods}

To test the proposed hypotheses, this study uses a quantitative research method through questionnaires. The study applies a linear structural model with the support of SPSS 23 and Amos 23 software. The scales in the research model are selected from previous studies and adjusted and redesigned accordingly with the context of SHC consumption of Vietnamese consumers (Table 1). In order to improve the reliability of the scales, the research applies the reverse translation method with the support of 3 experts in language and marketing. The scales are translated from English to Vietnamese and then translated back to English for comparison, contrast and change accordingly. The questions in the survey are in the form of 5-point Likert scale with 1 being "strongly disagree" and 5 being "strongly agree".

In the exploratory factor analysis (EFA), the sample size is usually determined based on two factors: the minimum size and the number of observed variables included in the analysis. [15] suggested that for exploratory factor analysis (EFA), the sample size should be at least 50 and the observation/items ratio should be $5: 1$, that is, 1 measurement variable requires 5 observations. In this study, the author designed a survey with 31 questions. Thus, to carry out research with Cronbach's Alpha reliability analysis and exploratory factor analysis (EFA), the research sample needs at least 150 questionnaires.

The study sample was selected by convenience sampling method. The questionnaire was designed in google form, with the link sent to the consumers aged 18-41 years old living in Vietnam via email and messenger on Facebook. The investigation was conducted between March 18, 2020 and April 28, 2020. The results obtained 823 valid questionnaires. The sample size qualifies for the follow-up analysis of this study.

TABle 1. The SCALES USED IN THE RESEARCH MODEL

\begin{tabular}{|l|l|l|l|}
\hline & Scales & $\begin{array}{l}\text { Number of } \\
\text { variables }\end{array}$ & Source of the scale \\
\hline 1 & Low price motive & 7 & $\begin{array}{l}\text { Lichtenstein et al. } \\
(1990) .\end{array}$ \\
\hline 2 & Fair price motive & 8 & Roux v\& Guiot (2008) \\
\hline 3 & Ethical and ecological & 2 & Shim (1995) \\
\hline 4 & $\begin{array}{l}\text { Anti-ostentation } \\
\text { motivations }\end{array}$ & 5 & Roux \& Guiot (2008) \\
\hline 5 & Attitude & 3 & Hazen et al. (2017) \\
\hline 6 & Intention to buy SHC & 5 & $\begin{array}{l}\text { Holak \& Lehmann } \\
(1990)\end{array}$ \\
\hline
\end{tabular}

Source: Compiled by the author

\section{Research Results}

\section{A. Measurement validation and reliability}

Evaluate the reliability of the scale through Cronbach's Alpha coefficient. The test results based on SPSS.23 software showed that: the scale of Low price motive eliminated one observation (Lop5), the rest of the scales were satisfactory.
Then perform EFA exploratory factor analysis. The KMO coefficient calculated from the survey sample is $0.960>0.5$. Thus, the survey sample size is eligible to perform exploratory factor analysis.Barllet's test with the hypothesis $\mathrm{H} 0$ : the correlation level between the observed variables is zero in the population is statistically significant because the P-value (Sig.) determined from the survey sample is 0.000 smaller than the significance level of 0.05 . Therefore, it is possible to reject the hypothesis $\mathrm{H} 0$ or it can be concluded that the observed variables are correlated with each other in the population. With Promax rotation and displaying only load factors $>0.5$, it shows that all observed variables have load coefficients $>0.5$ which are considered to have practical significance (Hair et al., 2014), so All these observed variables were kept for use in the next analysis steps. In which, the results of EFA analysis for ethical and ecological and anti-ostentation motivations are downloaded with the same factor.Ethical and ecological and anti-ostentation motivations are two drivers of critical motives (Guiot and Roux 2010). Thus, through exploratory factor analysis with a dataset collected from a Vietnamese consumer survey, it has been shown that for Vietnamese consumers, Ethical and ecological and anti-ostentation motivations convergence on one factor.Therefore, naming this new factor is a critical motivation, the observed variables keep their original symbols.

To evaluate whether the model and the scale meet the requirements of a model, it is necessary to use confirmatory factor analysis (CFA). Hair et al. (2010) the indicators considered to evaluate Model Fit include: CMIN/df $\leq 2$ is good, CMIN/df $\leq 5$ is acceptable; $\mathrm{CFI} \geq 0.9$ is good, CFI $\geq 0.95$ is very good, CFI $\geq 0.8$ is acceptable; TLI $\geq 0.9$ is good, TFI $\geq$ 0.95 is very good; GFI 0.9 is good, GFI $\geq 0.95$ is very good RMSEA $\leq 0.08$ is good, RMSEA $\leq 0.03$ is very good. CFA analysis results from the survey sample have TLI $=0.940>$ $0.9 ; \mathrm{CFI}=0.946>0.9 ; \mathrm{CMIN} / \mathrm{df}=3.3745<5$; $\mathrm{RMSEA}=$ $0.058<0.08$. Therefore, the calculated results show that the model's indexes are satisfied, the model is accepted with the research data.

TABLE 2. THE RESUlts OF THE DISCRIMINANT AND RELIABILITY TEST IN THE CFA ANALYSIS

\begin{tabular}{|c|c|c|c|c|c|c|c|c|c|c|c|}
\hline & CR & AVE & MSV & SQRAVE & $\operatorname{MaxR}(\mathrm{H}$ & Itt & & Cit & Fpr & Lop & Att \\
\hline Itb & 0.899 & 0.642 & $\begin{array}{l}2 \quad 0.489 \\
\end{array}$ & 0.80 & 0.9 & & 1.000 & & & & \\
\hline Cit & 0.899 & 0.599 & $\begin{array}{ll}9 & 0.404 \\
\end{array}$ & 0.77 & 0.9 & & 0.613 & $\begin{array}{ll}3 & 1.000 \\
\end{array}$ & & & \\
\hline Fpr & 0.932 & 0.662 & $\begin{array}{ll}2 & 0.489 \\
\end{array}$ & 0.81 & 0.9 & & 0.699 & $\begin{array}{ll}9 & 0.601 \\
\end{array}$ & $\begin{array}{ll}1 & \mathbf{1 . 0 0 0} \\
\end{array}$ & & \\
\hline Lop & 0.916 & 0.646 & $\begin{array}{ll}6 & 0.381 \\
\end{array}$ & 0.80 & 0.9 & & 0.542 & $\begin{array}{ll}2 & 0.598 \\
\end{array}$ & $\begin{array}{ll}8 & 0.617 \\
\end{array}$ & $\begin{array}{l}7 \quad \mathbf{1 . 0 0 0} \\
\end{array}$ & \\
\hline Att & 0.891 & 0.733 & $\begin{array}{ll}3 & 0.410 \\
\end{array}$ & 0.85 & 0.9 & & 0.640 & $\begin{array}{ll}0 & 0.636 \\
\end{array}$ & $\begin{array}{ll}6 \quad 0.630 \\
\end{array}$ & $\begin{array}{ll}0 & 0.584 \\
\end{array}$ & $4 \quad 1.00$ \\
\hline
\end{tabular}

Source: Data analysis results by AMOS 23.0

According to [15], the thresholds for comparison of the indicators should be as follows: composite reliability $\mathrm{CR} \geq$ 0.7 ; AVE convergence $\geq 0.5$; discriminant response when the maximum individual variance MSV is less than the extracted mean variance AVE; index square root of average variance extracted (Square Root of AVE - SQRTAVE) > index determining correlation (Inter Construct Correlations).Looking at the results in Table 2, it shows that the values in the CR column are all $>0.7$, so the reliability of the 
scale is guaranteed; the values in the AVE column are all $>$ 0.5 so convergence is guaranteed; MSV values < AVE; SQRTAVE values (numbers in bold above diagonal) $>$ correlation indices (numbers below diagonal), so discriminability is guaranteed.Therefore, all these scales are eligible for further use for further studies.

\section{B. Moderation tests}

The results of running the SEM model for the research model to evaluate the motivations affecting the intention to buy used clothes of consumers are shown in Figure 2.The model's suitability assessment indicators are valuable. value as follows: $\mathrm{CMIN} / \mathrm{df}=3.745<5 ; \mathrm{TLI}=0.940>0.9$; $\mathrm{CFI}=$ $0.946>0.9$; and RMSEA $=0.058<0.08$. As such, the model is considered acceptable for performing SEM analysis.

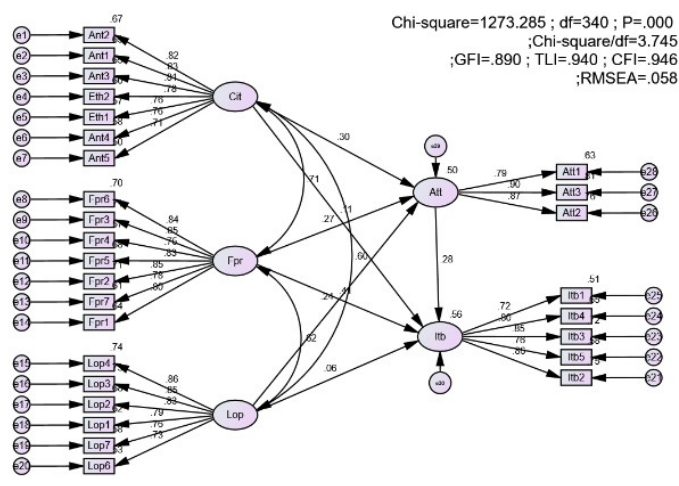

Figure 2. Structural Model Analysis (SEM) - Normalized Form

Source: Data analysis results by AMOSS 23.0

TABLE 3. REgRession Weight TABLE FOR RESEARCH MODEL

\begin{tabular}{|l|l|l|c|c|c|c|c|}
\hline & & & $\begin{array}{c}\text { Unsta } \\
\text { ndardi } \\
\text { zed } \\
\text { coeffi } \\
\text { cient }\end{array}$ & $\begin{array}{c}\text { Standar } \\
\text { dized } \\
\text { coeffici } \\
\text { ent }\end{array}$ & S.E. & C.R. & P \\
\hline Att & $<---$ & Cit & .331 & .305 & .051 & 6.528 & $* * *$ \\
\hline Att & $<---$ & Fpr & .271 & .268 & .048 & 5.703 & $* * *$ \\
\hline Att & $<---$ & Lop & .238 & .236 & .041 & 5.845 & $* * *$ \\
\hline Itb & $<---$ & Att & .277 & .277 & .042 & 6.580 & $* * *$ \\
\hline Itb & $<---$ & Cit & .119 & .110 & .049 & 2.418 & .016 \\
\hline Itb & $<---$ & Fpr & .416 & .409 & .047 & 8.772 & $* * *$ \\
\hline Itb & $<---$ & Lop & .063 & .063 & .039 & 1.607 & .108 \\
\hline R2 & & & & .502 & & & \\
\hline Att & & & & .564 & & & \\
\hline Itb & & & & & & \\
\hline
\end{tabular}

Source: Data analysis results by AMOSS 23.0

From the results of the unnormalized regression weight table for the research model (table 3), it is shown that at the $5 \%$ level of significance, the relationships between low price motivations, fair price motive and critical motivations is statistically significant in the relationship that affects the attitude to buy SHC. Fair price motives and critical motives have a direct impact on the intention to buy SHC. The low price motive has an indirect impact on the intention to buy SHC through the intermediate variable attitude. Consumer attitudes have an influence on their purchase intention.

\section{Conclusion}

\section{A. Implications for theory}

This study also contributes to the SHC purchasing literature. More specifically, the critical motives that include both ethical and ecological motivations and anti-ostentation motivations; Fair price motive has an influence on consumers' attitude and intention to buy used clothing. The low price motive has an indirect impact on the intention to buy used clothes through the intermediate variable attitude.

Overall, consistent with TRA [1] and TPB ([2], it was found that attitude mediates the effects of three different cognitive and motivational groups on purchase intention consumer SHC.

\section{B. Practical implications}

Economic incentives (in the form of fair or lower prices) are only one of the preconditions for consumers to buy SHC.

Ecological motivations and anti-ostentation motivations to play a pivotal role in shaping attitudes towards SHC buying. So, put more emphasis on green model and develop new communication strategies and value propositions around green and/or sustainable fashion [8, 20, 25] This seems to be the way forward for fashion companies willing to incorporate environmental goals into their corporate mission.

Consumer attitudes are positively influenced by social and economic motivations. Therefore, it is advisable to focus on this impact to stimulate consumers to shop.

\section{Limitations}

Beside the contribution this research also exist some limitations. It is recommended to classify SHC products to have a more specific view of the impact of each motor on consumers' purchase intention Moreover, analyze the impact of demographic variables to clearly see the difference of each customer group.

\section{REFERENCES}

[1] Ajzen, I. (1991). The theory of planned behavior. Organizational Behavior and Human Decision Processes, 50, 179-211. https://doi.org/10.1016/ 0749-5978(91)90020-T

[2] Ajzen, I., \& Fishbein, M. (1980). Understanding attitudes and predicting social behaviour. Englewood Cliffs, NJ: Prentice-Hall.

[3] Benoit, S., Baker, T. L., Bolton, R. N., Gruber, T., \& Kandampully, J. (2017). A triadic framework for collaborative consumption (CC): Motives, activities and resources \& capabilities of actors. Journal of Business Research, 79, 219-227. https://doi.org/10.1016/ j.jbusres.2017.05.004

[4] Bianchi, C., \& Birtwistle, G. (2012). Consumer clothing disposal behaviour: A comparative study. International Journal of Consumer Studies, 36(3), 335-341. https://doi.org/10.1111/j.1470-6431 .2011.01011.x

[5] Brace-Govan, J., Binay, I., (2010). 'Consumption of disposed goods for moral identities: a nexus of organization, place, things and consumers'. J. Consum. Behav. 9, 69-82.

[6] Carrigan, M., Moraes, C. \& McEachern, M. (2013), 'From conspicuous to considered fashion: A harm-chain approach to the responsibilities of luxury-fashion businesses'. Journal of Marketing Management, Vol. 29, No. 11-12, pp. 1277-1307. 
[7] Cervellon, M.C., Carey, L. \& Harms, T. (2012). Something old, something used: determinants of women's purchase of vintage fashion vs. second-hand fashion. International Journal of Retail \& Distribution Management, 40, 956-974.

[8] Chan, R. Y. K. (2001). Determinants of Chinese consumers' green purchase behavior. Psychology \& Marketing, 18(4), 389-413. https:// doi.org/10.1002/mar.1013

[9] Corvellec, H. A. (2017). 'Evidencing the waste effect of ProductService Systems (PSSs)'. Journal of Cleaner Production, 14-24.

[10] Crosno, J. L., \& Cui, A. P. (2018). Something old, something new: The role of partitioned pricing in consumers' preference for new versus used products. Journal of Consumer Marketing, 35(4), 353 365. https://doi. org/10.1108/JCM-02-2017-2091

[11] Dahlstrand, U., \& Biel, A. (1997). Pro-environmental habits: Propensity levels in behavioral change1. Journal of Applied Social Psychology, 27(7), 588-601. https://doi.org/10.1111/j.15591816.1997.tb00650.x

[12] Farrant, L., Olsen, S. I., \& Wangel, A. (2011). 'Environmental benefits from reusing clothes'. International Journal of Life Cycle Assess, 15, 726- 736 .

[13] Guiot, D. and Roux, D. (2010), A second-hand shoppers' motivation scale: antecedents, consequences and implications for retailers, Journal of Retailing, Vol. 86, No. 4, pp. 355-371.

[14] Gullstrand Edbring, E., Lehner, M. \& Mont, O. (2016). Exploring consumer attitudes to alternative models of consumption: motivations and barriers. Journal of Cleaner Production [Online]. 123: 5-15.

[15] Hair, J. F., Black, W. C., Babin, B. J., \& Anderson, R. E. (2010) Multivariate data analysis: A global perspective (7th ed.). Upper Saddle River, NJ: Pearson Education.

[16] Hansen, K. T. (2000). Other people's clothes? The international second-hand clothing trade and dress practices in Zambia. Fashion Theory, 4(3), 245-274.

[17] Hazen, B. T., Mollenkopf, D. A., \& Wang, Y. (2017). Remanufacturing for the circular economy: An examination of consumer switching behavior. Business Strategy and the Environment, 26(4), 451-464. https://doi.org/10.1002/bse.1929

[18] Holak, S. L. \& Lehmann, D. R. (1990), Purchase Intentions and the Dimensions of Innovation: An Exploratory Model. Journal of Product Innovation Management, Vol. 7, No. 1, pp. 59-73.

[19] Joy, A., Sherry, J. F. J, Venkatesh, A., Wang, J. \& Chan,R. (2012) 'Fast Fashion, Sustainability, and the Ethical Appeal of Luxury Brands', Fashion Theory, 16:3, 273 295, DOI 10.2752/175174112X13340749707123.

[20] Lang, C., \& Joyner Armstrong, C. M. (2018). Collaborative consumption: The influence of fashion leadership, need for uniqueness, and materialism on female consumers' adoption of clothing renting and swapping. Sustainable Production and Consumption, 13, 37-47. https:// doi.org/10.1016/j.spc.2017.11.005

[21] Lichtenstein, D.R., Netemeyer, R.G., Burton, S., (1990). Distinguishing Coupon Pro- neness from Value Consciousness: An Acquisition-Transaction Utility Theory Perspective. J. Mark., 54-67.

[22] Luchs, M., Naylor, R. W., Rose, R. L., Catlin, J. R., Gau, R., Kapitan, S., ... Weaver, T. (2011). Toward a sustainable marketplace: Expanding options and benefits for consumers. Journal of Research for Consumers, 19, 1-12.

[23] Mano, H., \& Elliott, M. T. (1997). Smart shopping: The origins and consequences of price savings. In M. Brucks \& D. J. MacInnis (Eds.) Advances in Consumer Research (24, pp. 504-510). Provo, UT: Association for Consumer Research
[24] McKinsey \& Company. Retrieved from https://www.mckinsey.com/ industries/retail/our-insights/the-state-of-fashion-2019-a-year-ofawakening

[25] Pagiaslis, A., \& Krontalis, A. K. (2014). Green consumption behavior antecedents: Environmental concern, knowledge, and beliefs. Psychology \& Marketing, 31(5), 335-348. https://doi.org/10.1002/ mar.20698

[26] Pal, R., \& Gander, J. (2018). Modelling environmental value: An examination of sustainable business models within the fashion industry. Journal of Cleaner Production, 184, 251-263. https://doi. org/10.1016/j.jclepro.2018.02.001

[27] Paul, J., Modi, A., \& Patel, J. (2016). Predicting green product consumption using theory of planned behavior and reasoned action. Journal of Retailing and Consumer Services, 29, 123-134. https:// doi.org/10.1016/ j.jretconser.2015.11.006

[28] Phipps, M., Ozanne, L. K., Luchs, M. G., Subrahmanyan, S., Kapitan, S., Catlin, J. R., ... Weaver, T. (2013). Understanding the inherent complexity of sustainable consumption: A social cognitive framework. Journal of Business Research, 66(8), 1227-1234. https:// doi.org/10.1016/j.jbusres.2012.08.016

[29] Roux, D. \& Guiot, D. (2008). Measuring second hand shopping motives, antecedents and consequences. Recherche et Applications en Marketing, 23(4), 63-94.

[30] Roux, D., Korchia, M., (2006). 'Am I what I wear? An exploratory study of symbolic meanings associated with secondhand clothing'. Adv. Consum. Res. 33 (1), 29-35.

[31] Shim, S. (1995). Environmentalism and consumers' clothing disposal patterns: An exploratory study. Clothing \& Textiles Research Journal, 13(1), 38-48.

[32] Tanner, C., \& Wölfing Kast, S. (2003). Promoting sustainable consumption: Determinants of green purchases by Swiss consumers. Psychology \& Marketing, 20(10), 883-902. https://doi.org/10.1002/ mar. 10101

[33] Thøgersen, J., Jørgensen, A.-K., \& Sandager, S. (2012). Consumer decision making regarding a green everyday product. Psychology \& Marketing, 29(4), 187-197. https://doi.org/10.1002/mar.20514

[34] Turunen, L.L.M., Leipämaa-Leskinen, H., (2015). Pre-loved luxury: identifying the meanings of second-hand luxury possessions. J. Prod. Brand Manag. 24 (1), 57-65.

[35] Vinces, J. P., Solakis, K. \& Guillen, J. (2020). 'Environmental knowledge, the collaborative economy and responsible consumption in the context of second-hand perinatal and infant clothes in Spain'. Resources, Conservation \& Recycling, 159.

[36] Vining, J., \& Ebreo, A. (1990). What makes a recycler?: A comparison of recyclers and nonrecyclers. Environment and Behavior, 22(1), 55-73. https://doi.org/10.1177/0013916590221003

[37] WRAP (2017). Valuing our clothes: The cost of UK fashion. The Waste and Resources Action Programme (WRAP), Banbury, Oxon. Retrieved from http://www.wrap.org.uk/sustainable-textiles/valuingour-clothes $\% 20$

[38] Williams, C.C., Paddock, C., (2005). 'The meanings of informal and second-hand retail channels: some evidence from Leicester'. Int. Rev. Retail, Distrib. Consum. Res. 13 (3), 317-336.

[39] Yan, R.-N., Bae, S. Y., \& Xu, H. (2015). Second-hand clothing shopping among college students: The role of psychographic characteristics. Young Consumers, 16(1), 85-98. https://doi.org/ 10.1108/YC-02- 2014-00429

[40] Zamani, B. S., Andin, G. \& Peters, G.M. (2017). 'Life cycle assessment of clothing libraries: can collaborative consumption reduce the environmental impact of fast fashion?', Journal of Cleaner Production, 162, 1368-1372. 